\title{
Possibilities for implementation of professional competencies of physical therapists working in teams of rehabilitation specialists of education and health protection systems
}

\author{
ORCID ID: 0000-0002-4788-3459 \\ ${ }^{1}$ Department of Holistic Medicine and Rehabilitation, Klaipeda University, Lithuania \\ ${ }^{2}$ Department of Social Work, Klaipeda University, Lithuania \\ ${ }^{3}$ Dolphin Assisted Therapy Centre of the Lithuanian Sea Museum, Klaipeda, Lithuania
}

INGA ŠIMKUTE் KARALEVIČIENE் ${ }^{1, A-G}$, DAIVA MOCKEVIČIENE்1, B-F, BRIGITA KREIVINIENE் ${ }^{2,3}$ B-F

ORCID ID: 0000-0003-3316-096X

A - Study Design, B - Data Collection, C - Statistical Analysis, D - Data Interpretation, E - Manuscript Preparation, F - Literature Search, G - Funds Collection

Summary Background. The paper deals with the possibilities for implementation of professional competences of physical therapists working in different systems of education and health protection with regard to the holistic health concept, psychophysical education and interdisciplinary collaboration inside rehabilitation teams.

Objectives. The main objective of the study was to compare the possibilities for implementation of professional competences of physical therapists working in rehabilitation teams of education and health protection systems.

Material and methods. The survey encompassed 200 physical therapists working in the education $(n=98)$ and health protection $(n=102)$ systems of Lithuania. A questionnaire-based method employing closed-type questions was used, which was aimed at revealing whether implementation of professional competences of physical therapists working in different systems differed.

Results. The competences of communication and collaboration, i.e. interdisciplinary activities inside rehabilitation teams, were more developed by physical therapists working in the education system $(t=23.483, d f=2, p=0.001)$. In the process of physical diagnosis, physical therapists of the health system make a diagnosis of physical therapy independently. The same statistically significant difference was also noticed in the aspect of communication of groups of these specialists when psychosocial problems occur, specifically: $t=14.768, d f=3, p=0.002$. Physical therapists of the education system more actively participate in qualification development, delivery of talks at conferences and organising health promotion programmes, even though no statistically significant difference was found $(t=4.830, d f=3, p=0.185)$.

Conclusions. The competences of interdisciplinary collaboration are more developed by physical therapists working in the education system; whereas physical therapists working in the health system are more concerned with the making of a physical therapy diagnosis, design of a programme and application of more diverse methods.

Key words: clinical competence, physical education and training, rehabilitation.

Šimkutè Karalevičienè I, Mockevičienè D, Kreivinienè B. Possibilities for implementation of professional competencies of physical therapists working in teams of rehabilitation specialists of education and health protection systems. Fam Med Prim Care Rev 2019; 21(2): 158-163, doi: https://doi.org/10.5114/fmpcr.2019.84546.

\section{Background}

Throughout Europe, health is perceived as the comprehensive spiritual, physical and social welfare of an individual and society [1]. The holistic concept of health encompasses the understanding of various health conditions. A contemporary individual faces many health risk factors every day. The Amsterdam, Luxembourg Declarations, Ljubljana, Ottawa, Jakarta and European Social Charters emphasise active engagement of society members in health maintenance and protection. The order signed by the Minister of Health of the Republic of Lithuania ensures the right of citizens to have access to rehabilitation services [2]. A problematic situation occurs in Lithuania because of the establishment of the disease treatment paradigm and not the accentuation of preventive education [3]. Aiming at a comprehensively healthy individual, the systematic development of the goals reaching for prevention, education and rehabilitation is necessary [4-6]. Holistic health is grounded on the paradigm of psychophysical development, which is important to the existence of a healthy society [7]. This is the reason why European countries, including Lithuania, have an increased demand for holistic prevention and education specialists. A changing societal attitude towards the role of physical therapists stimulates increasing the spread of these specialists in various spheres of education and health. Professional regulation of specialist training ensures practical implementation of the health policy carried out by these specialists $[8,9]$. The order issued by the Minister of Health of the Republic of Lithuania, "A Physical Therapist. The Rights, Duties, Competence and Responsibility", is one of the major normative acts defining the most important professional competences of specialists of physical therapy. Meanwhile, there are no normative acts which regulate the specificity of the work of physical therapists in the education system.

Various scientific sources indicate that implementation of the professional competences (knowledge, abilities and skills) of specialists in practice is highly important while seeking to meet the modern holistic concept of health protection and education $[1,10]$. In both health and education areas, physical therapy plays an important role; and implementation of the competences is highly important and needed [2]. Lithuanian scientific research works reveal that physical therapists insufficiently implement their competences of communication and collaboration. These issues are dealt with throughout Europe, 
too; nevertheless, it is noted that there is a lack of scientific research on this topic $[10,11]$. Therefore, the current study aims at investigating competences sought by specialists working in different spheres.

\section{Objectives}

The objective is to reveal the differences for implementation of professional competences of physical therapists working in institutions of health care and education systems.

\section{Material and methods}

The research included a questionnaire-based survey employing a nominal closed-type questionnaire. The research conducted preserving all requirements of ethics applied for such kind of research. The questionnaire was developed operationalising the object of research, based on scientific literature. The questionnaire comprises four blocks of questions: demographic, special abilities, interdisciplinary collaboration and personal development $[8,9,12-14]$. The block of questions on special abilities sought to examine the making of a physical therapy diagnosis, application of methods in practice, etc. [14-17]. The block of questions on interdisciplinary collaboration aimed at analysing the specialists' attitude towards team work [18-20]. The block of questions on personal development was designed to find out the possibilities for qualification development of the specialists.

The data was processed by employing statistical data analysis. The collected data was analysed and compared by employing statistical calculations facilitated by SPPS and MS EXCEL software. The SPPS software calculated the chi-square criterion according to Pearson's formula. The calculated values: $T$-value - the value of Pearson's chi-square criterion, $d f$ - number of degrees of freedom, Asymp. Sig. (2-sided).

\section{Results}

\section{Participants}

Physical therapists who participated in the research were gathered from five major cities of Lithuania, as well as remote regions (Fig. 1). Those physical therapists were working in the institutions of the education system $(n=98)$, others - in institutions of the health protection system $(n=102)$. The majority of respondents were up to 40 years of age (Fig. 2), and their duration of work was from 1 to 10 years (Fig. 3). Respondents who participated in the research had two different backgrounds of physiotherapy program.
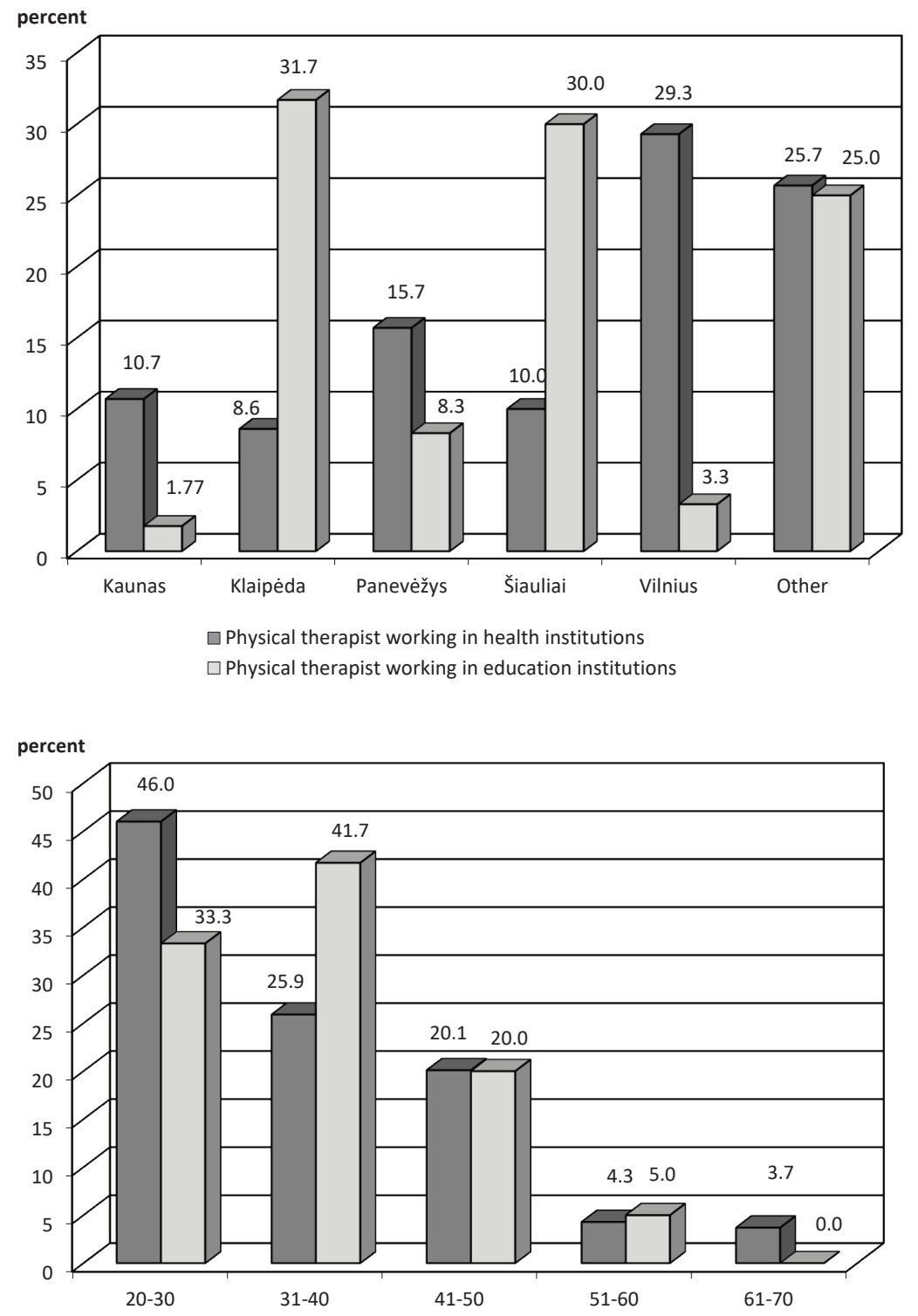

$\square$ Physical therapist working in health institutions

$\square$ Physical therapist working in education institutions
Figure 1. Distribution of the respondents according to place of living (\%)
Figure 2. Distribution of the respondents according to age (\%) 


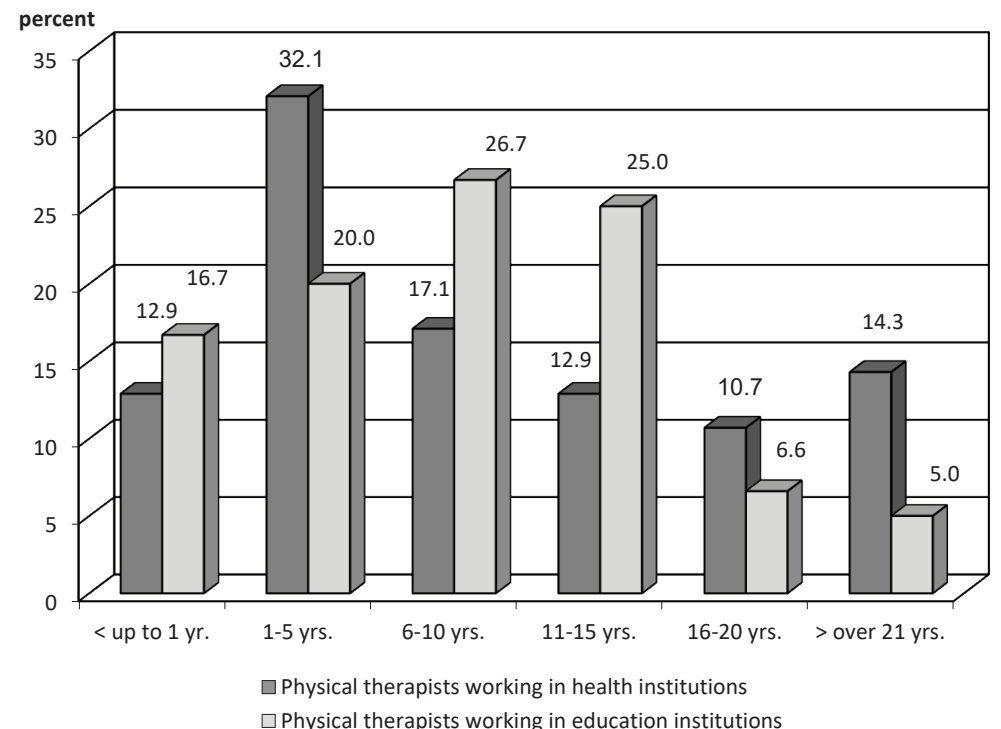

Figure 3. Distribution of the respondents according to duration of work (\%)

\section{Descriptive data}

A questionnaire-based survey was used to find out what study programmes had been completed by the respondents. It was found out that $52.1 \%$ of the surveyed physical therapists had completed university studies (Bachelors and Masters, Fig. 4), and the rest $(47.9 \%)$ had graduated from colleges (Professional Bachelors). Only $13.6 \%$ of physical therapists holding a Professional Bachelor's Degree were working in the education system, and the respondents working in the health system distributed evenly in terms of their academic degrees. The respondents' fields of specialisation were (Fig. 5): orthopaedics, neurology, rehabilitation, surgery, therapy or other.
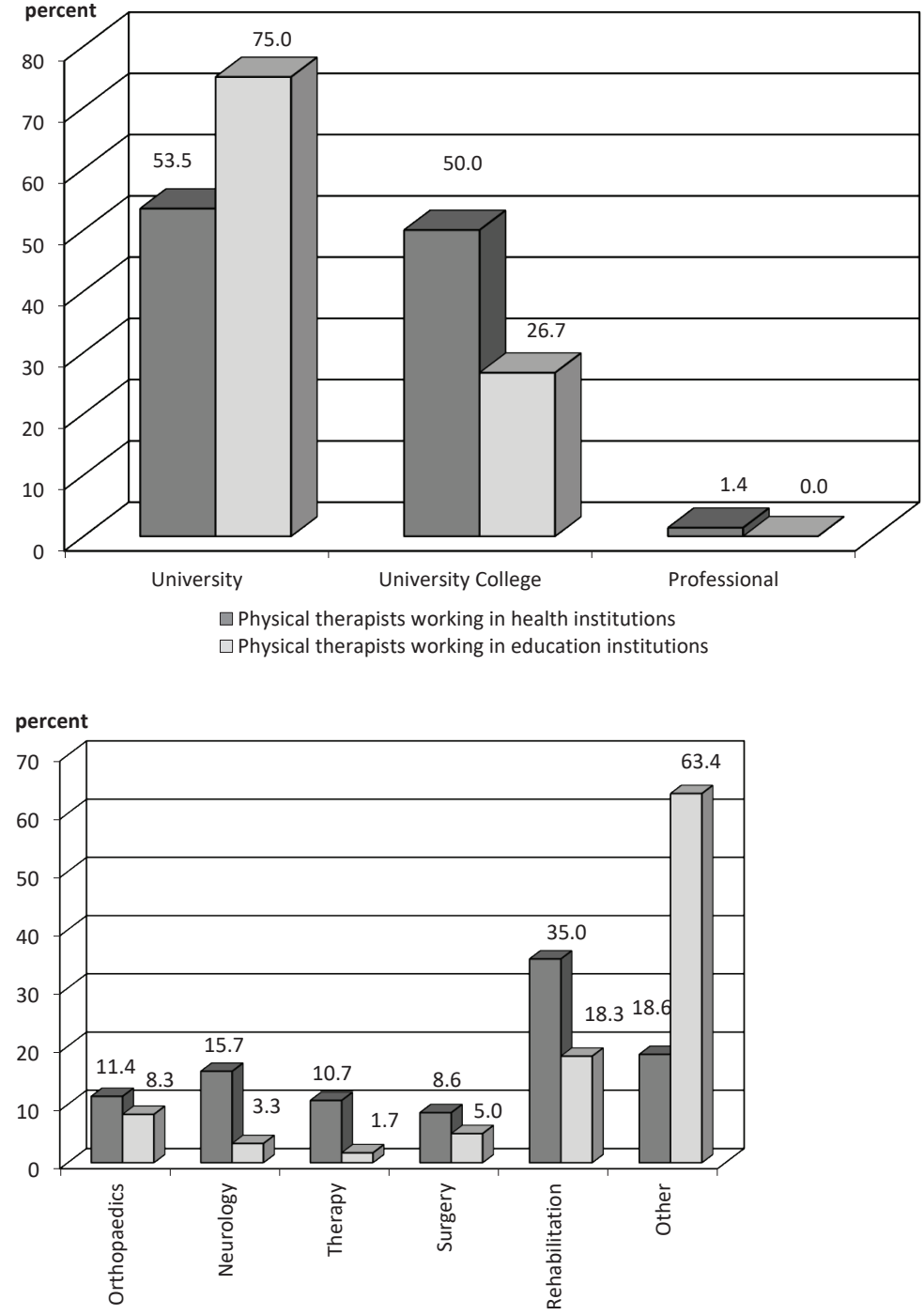

$\square$ Physical therapists working in health institutions

$\square$ Physical therapists working in education institutions
Figure 4. Distribution of the respondents according to educational background (\%)
Figure 5. Distribution of the respondents according to their field of specialisation (\%) 


\section{Outcome data}

Aiming to evaluate implementation of professional competences of physical therapists, the development of special abilities (making of a physical therapy diagnosis, design and assessment of the effectiveness of individual and group programmes of physical therapy, application of physical therapy methods and combination of these with physiotherapy, provision of first aid, compliance with work safety requirements) in work practice was analysed. The analysis of characteristics of assessment of motor skills did not point out any statistically significant difference $(t=3.466, d f=3, p=0.325)$. A physical therapy diagnosis is much more often made by specialists working in the health system and by those who graduated from universities $(t=23.483$, $d f=2, p=0.001$ ) (Fig. 6).

More than half of physical therapists working in institutions of the health protection system (55\%) independently design individual programmes of physical therapy, and physical therapists working in the education system do this as follows: $30 \%$ ( $t=14.502, d f=2, p=0.001)$.

Aiming to compare the practical implementation of specialists' functional abilities, frequency of application of various methods in work practice was analysed. The obtained results allow us to state that a majority of the respondents constantly ap- ply stretching exercises, remedial exercises and Bobath in their work practice; the PNF and Vojta methods are applied less often.

Specialists working in the health system more frequently combine methods of physical therapy and physiotherapy $(t=37.513, d f=2, p=0.001)$.

The analysis of interdisciplinary collaboration abilities revealed statistically significant differences between the groups ( $t=42.861, d f=2, p=0.001$ ). It was found that more physical therapists working in the education system worked in a team and more often communicate with other specialists of an institution to deal with occurring psychological, social and communication problems (53.3\%); and in the group of those who work in the health system only, $26.4 \%(t=14.768, d f=3, p=0.002)$ demonstrated these activities. However, patients are more often taught to use compensatory technology by physical therapists working in institutions of the health system (specifically, $64.3 \%$ and $40.0 \% ; t=13.965, d f=3, p=0.003$ ).

The analysis of the aspects of qualification development revealed that similar amounts of physical therapists participate in events dedicated to qualification development (seminars, training, etc.). Even though more physical therapists working in the education system take part in conferences on their own initiative, the differences between the groups are insignificant ( $t=$ 4.830, $d f=3, p=0.185$ ) (Fig. 7).
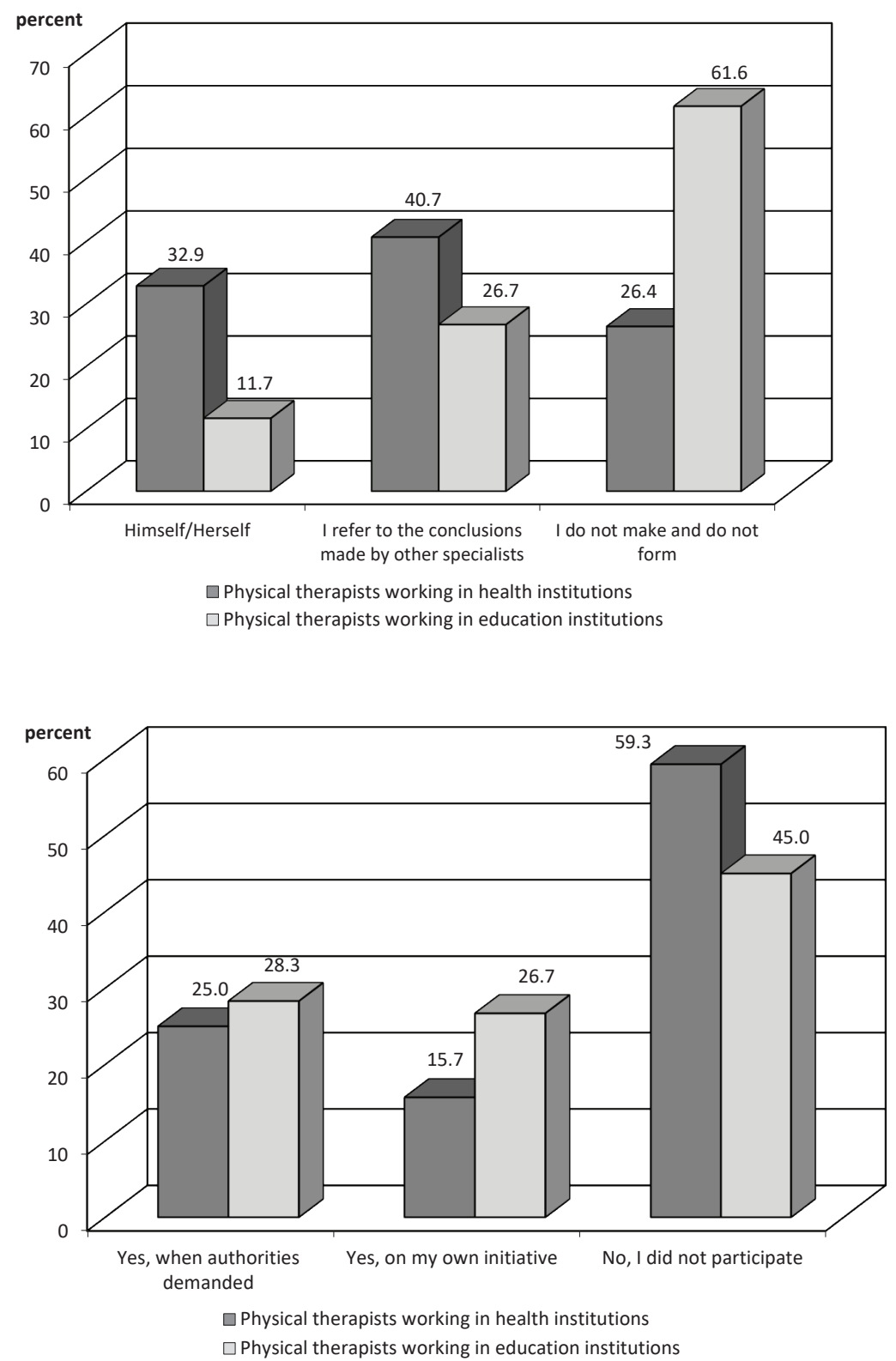

Figure 6. Distribution of the respondents according to the making of a physical therapy diagnosis (\%)

Figure 7. Distribution of the respondents according to participation in seminars and oral presentations (\%) 


\section{Discussion}

This research reveals that despite the area of education, physical therapists working in both education and health protection systems do the same job. However, competences of interdisciplinary collaboration are more strongly developed by physical therapists of the education system. A statistically significant difference between both groups of specialists was found in the process of making a diagnosis $(t=23.483, d f=2, p=0.001)$ : physical therapists of the health system are more inclined to diagnose independently. Comparisons of these results with other scientific research studies point out that holistic methods applied by physical therapists while involving other specialists in practice can significantly improve patients' health [21], and knowledge of communication with a patient and sociocultural aspects are fundamental in the successful process of physical therapy [22]. A statistically significant difference $(t=14.768$, $d f=3, p=0.002$ ) was calculated in the communication characteristics of these two groups solving psychosocial problems. Even though no statistically significant difference between the specialists was found ( $t=4.830, d f=3, p=0.185$ ), it can be stated that physical therapists working in the education system more actively participate in events dedicated to qualification development, share experiences, prepare presentations, seminars and design health promotion programmes. These research findings in Lithuania are closely related to the tendencies of the global manifestations of professional competences of physical therapists. The modern concept of physical therapy encompasses the specialist autonomisation process and the necessity to develop more awareness in patients [23]. Moreover, the present concept of medicine complies with the attitude that team work is more beneficial to the process of patient treatment. Such collaboration is based on an interdisciplinary approach and respect, as well as collaboration among patient, relatives who take care of him/her and medical professionals. One of the contemporary tendencies deals with an increasing number of countries where physical therapists are allowed to work independently, without appointments of rehabilitologists. On the one hand, it demonstrates their need to expand communication and collaboration with a patient; on the other hand, these specialists are perfectly able to take the inter-competences of other specialists and implement them [23], e.g. development of clinical physical therapy practice at the scientific level is related with successful implementation of the dual identity of a physical therapist [24].

\section{Limitations of the study}

Some limitations of this study should be noted. This research did not used a validated questionnaire. Due to the novelty of the study objective, psychosocial aspects are investigated in the professionalisation of physiotherapists. Therefore, the authors applied the construction of the questionnaire based on scientific literature. However, the data of this research shows the demand for development of adjacent investigations related to the context of interdisciplinary collaboration of physical therapists in the future.

\section{Conclusions}

Implementation of a majority of special competences in practice is much more developed by physical therapists working in the health protection system. Physical therapists working in the education system more strongly emphasise team work in their performance jointly with specialists, but also while engaging the families of patients.

Source of funding: This work was developed using the university's funds and authors' own research funds. Conflicts of interest: The authors declare no conflicts of interest.

\section{References}

1. Dooris M, Farrier A, Froggett L. Wellbeing: the challenge of 'operationalising' a holistic concept within a reductionist public health programme. Perspect Public Health 2018; 138(2): 93-99, doi: 10.1177/1757913917711204.

2. Lietuvos respublikos sveikatos apsaugos ministro j̇sakymas nr. V-473. Dél medicininés reabilitacijos ir sanatorinio (antirecidyvinio) gydymo organizavimo pakeitimo. Valstybès žinios 2018, 473, 6375 (in Lithuanian).

3. Effgen SA, Chiarello L, Milbourne LA. Updated competencies for physical therapists working in schools. Pediatr Phys Ther 2007; 19(4): 266-274.

4. Didjurgienè A. Šiuolaikinio specialisto kompetencijos: teorijos ir praktikos dermè. Tarptautiné moksliné-praktine konferencija (p. 70). Kaunas: Kauno kolegija; 2009 (in Lithuanian).

5. Žukauskienè, M. Curriculum modelling of the physiotherapy professional education. Summary of Doctoral Dissertation [dissertation]. Kaunas: Social sciences; 2011.

6. Žukauskienè M. Kineziterapeutu rengimas profesinei veiklai. Profesinis rengimas: tyrimai ir realijos. 2010; 10(19): $224-241$ (in Lithuanian).

7. Arena S. Advance competency in home healthcare for physical therapists. Home Health Now 2007; 35(9): 517-518.

8. Lietuvos respublikos sveikatos apsaugos ministro įsakymas. $2016 \mathrm{~m}$. vasario $5 \mathrm{~d}$. Nr. V-184. Vilnius. Dèl Lietuvos respublikos medicinos normos MN 124:2016 „Kineziterapeutas. Teisès, pareigos, kompetencija ir atsakomybė“ patvirtinimo (in Lithuanian).

9. Lietuvos Respublikos švietimo ir mokslo ministro 2015 m. liepos 23 d. j̨sakymas Nr. V-798.Vilnius. Dèl reabilitacijos studiju krypties aprašo patvirtinimo „Reabilitacijos studijų krypties aprašas“ (in Lithuanian).

10. Di Tondo S, Ferretti F, Bielli S. Assessment of core competencies of physical therapists among students and professionals in Italy: a cross-sectional study. J Allied Health 2018; 47(2): 133-140.

11. Weaver P, Cothran D, Dickinson S, et al. Physical therapists' perspectives on importance of the early intervention competencies to physical therapy practice. Infants and Young Children 2018; 31(4): 261-274.

12. World confederation for physical therapy. WCPT guidelines for physical therapist professional entry-level education. 2007. Available from URL: https://www.wcpt.org/sites/wcpt.org/files/files/WCPT-PoS-Guidelines_for_Physical_Therapist_Entry-Level_Education.pdf.

13. World confederation for physical therapy. WCPT declaration of principle. 2007. Available from URL: http://www.wcpt.org/sites/wcpt. org/files/files/WCPT-Declarations_of_Principle.pdf.

14. Pukelis K. Gebejimas, kompetencija, mokymosi/studiju rezultatas, kvalifikacija ir kompetentingumas: teorinè dimensija. Aukštojo mokslo kokybe 2009; 6: 12-35 (in Lithuanian).

15. Laitinen-Väänänen S, Luukka M R, Talvitie U. Physiotherapy under discussion: a discourse analytic study of physiotherapy students' clinical education. Advances in Physiotherapy 2008; 10: 2-8.

16. Laitinen-Väänänen $S$, Talvitie $U$, Luukka MR. Clinical supervision as an interaction between the clinical educator and the student. Physiother Theory Pract 2007; 23(2): 95-103. 
17. Mažionienė A, Žydžiūnaitè V. Slaugos specialistų kompetencijų tobulinimo strategija socialinės partnerystės kontekste. Vadyba 2009; 1(14): 41-47 (in Lithuanian).

18. McAllister L, Higgs J, Smith J. Facing and managing dilemmas as a clinical educator. Higher Education Research \& Development 2008; 27(1): 1-13.

19. Skinner M. Physiotherapy education in New Zealand. Physical Therapy Reviews 2007; 12: 122-128.

20. Thompson D. The social meaning and function of humour in physiotherapy practice: an ethnography. Physiother Theory Pract 2010; 26(1): 1-11.

21. Adamczyk A, Kiebzak W, Wil-Franczuk M, et al. Effectiveness of holistic physiotherapy for low back pain. Ortop Traumatol Rehabil 2009; 11(6): 562-576.

22. Jorgensen P. Concepts of body and health in physiotherapy: the meaning of the social/cultural aspects of life. Physiother Theory Practice 2009; 16(2): 105-115.

23. Higgs J, Jensen GM, Loftus S, et al., eds. Clinical reasoning in the health professions. 4th ed. Elsevier; 2019.

24. Kluijtmans M, Haan E, Akkerman S, et al. Professional identity in clinician-scientists: brokers between care and science. Med Educ 2017; 51(6): 645-655.

Tables: 0

Figures: 7

References: 24

Received: 1.02 .2019

Reviewed: 4.02.2019

Accepted: 19.02 .2019

Address for correspondence:

Brigita Kreivinienè, PhD, Assoc. Prof.

Dolphin Assisted Therapy Centre of the Lithuanian Sea Museum

Smiltynes str. 3

LT-93100 Klaipèda

Lithuania

Tel.: +37065367047

E-mail: b.kreiviniene@muziejus.It 